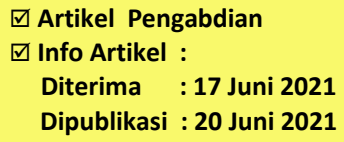

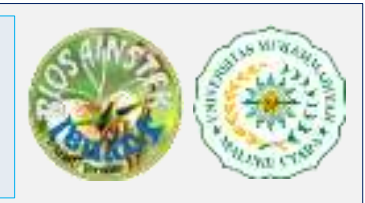

\title{
Kolaborasi Cegah Stunting dengan Mempersiapkan 1000 Hari Pertama Kehidupan (HPK) pada Masyarakat di Wilayah Kerja Puskesmas Perawatan Jambula
}

\author{
Nani Supriyatni', Andiani' ${ }^{1}$, Agustin Rahayu ${ }^{1}$, Suryani Mansyur ${ }^{1}$, Diah Merdekawati \\ Surasno1,Tutik Lestari1', Musiana1, Monisa A. Hi Djafar1 \\ ${ }^{1}$ Staf Pengajar Fakultas Ilmu Kesehatan, Universitas Muhammadiyah Maluku Utara. Ternate. Indonesia, \\ Email : naniskm@yahoo.com, andianimahbub@gmail.com,agustinyayu21@gmail.com,ryanimansyur@gmail.com, \\ diah.surasno.86@gmail.com, tutik198692@gmail.com, aryana.elnisa.at@gmail.co, lovesarichysaray@yahoo.com

\footnotetext{
${ }^{\square}$ Korespondensi : Nani Supriyatni, Universitas Muhammadiyah Maluku Utara. Ternate-Indonesia, Email : naniskm@yahoo.com
}

\begin{abstract}
ABSTRAK
Stunting adalah masalah gizi kronis yang dihadapi Indonesia saat ini. Data prevalensi balita stunting yang dikumpulkan World Health Organization (WHO), Indonesia termasuk ke dalam negara ketiga dengan prevalensi tertinggi di regional Asia Tenggara/South-East Asia Regional (SEAR). Rata-rata prevalensi balita stunting di Indonesia tahun 2005-2017 adalah 36,4\%. Prevalensi stunting menurut data Riskesdas 2018, terdapat 11,5\% balita yang sangat pendek dan 19,3\% balita pendek. Hal ini akan berdampak pada kualitas sumber daya manusia Indonesia di masa depan. Tujuan : memberikan edukasi gizi kepada kelompok sasaran yaitu ibu yang memiliki balita untuk meningkatkan pengetahuan gizinya sehingga dapat memperhatikan asupan gizi mulai masa kehamilan hingga anak bertumbuh secara optimal pada usia 2 tahun (1000 HPK). Metode: Kegiatan ini dilakukan dalam bentuk penyuluhan pada kelompok sasaran dengan melibatkan berbagai organisasi yang ada di masyarakat baik organisasi profesi yaitu PD IAKMI Maluku Utara dan juga organisasi daerah yaitu PW Nasyiatul Aisyiyah Maluku Utara. Jumlah peserta penyuluhan terbatas yaitu sebanyak 25 orang karena adanya kondisi pandemi covid-19. Untuk mengukur keberhasilan penyuluhan, maka diadakan pre test sebelum penyuluhan dan post-test setelah penyuluhan. Selain penyuluhan juga diadakan pembagian masker dan goody bag bertema stunting. Hasil: terdapat peningkatan pengetahuan sebanyak 20 orang yang meningkat pengetahuannya, nilai rata2 post test $(6,28)$ lebih dari nilai rata- rata pre test yaitu 4,88. Kesimpulan dan Saran: Ada peningkatan pengetahuan masyarakat mengenai penyebab stunting dan pencegahannya melalui persiapan 1000 HPK sehingga diharapkan kegiatan edukasi pada masyarakat dan kerjasama antar lembaga perlu ditingkatkan untuk menurunkan prevalensi stunting pada balita menjadi 14,9\% sesuai stranas 2025 .
\end{abstract}

Keyword: kolaborasi, stunting, 1000 HPK

\section{PENDAHULUAN}

Stunting adalah gangguan pertumbuhan linier yang tidak sesuai dengan umur. Kondisi ini diukur dengan panjang atau tinggi badan yang lebih dari minus dua standar deviasi median standar pertumbuhan anak dari WHO. Balita stunting termasuk masalah gizi kronik yang disebabkan oleh banyak faktor seperti kondisi sosial ekonomi, gizi ibu saat hamil, kesakitan pada bayi, dan kurangnya asupan gizi pada bayi. Balita stunting di masa yang akan datang akan mengalami kesulitan dalam mencapai perkembangan fisik dan kognitif yang optimal. (Kemenkes, RI, 2018)

Kejadian stunting balita merupakan cerminan kurang gizi kronik yang bermula sejak dalam kandungan, keadaan ini akan berlanjut hingga remaja bahkan menjadi dewasa stunting dengan segala konsekuensinya. Stunting disebabkan kekurangan gizi kronis dan infeksi berulang-ulang selama masa 1000 Hari Pertama Kehidupan (HPK) (WHA, 2012; WHO, 2014). Stunting menyebabkan rendahnya skor kognitif, peluang mengenyam pendidikan tinggi menjadi berkurang, dan pendapatannya juga 
rendah. Stunting menyebabkan tingginya risiko penyakit sindrom metabolik/penyakit tidak menular. (Siswati, 2018)

Saat ini jumlah kasus stunting balita paling tinggi bila dibandingkan dengan bentuk malnutrisi lainnya. Menurut Organisasi Kesehatan Dunia (WHO) 2017, sebanyak 155 juta (22,9\%) anak balita di dunia menderita stunting, sedangkan 41 juta balita (6\%) balita overweight dan 52 juta balita (7,2\%) kurus. Masalah stunting merupakan masalah intergenerasi yang memerlukan pemulihan dalam jangka waktu lebih lama bila dibandingkan dengan bentuk malnutrisi lain.

Rata-rata prevalensi balita stunting di Indonesia tahun 2005-2017 adalah 36,4\%. Prevalensi stunting menurut data Riskesdas 2018, terdapat $11,5 \%$ balita yang sangat pendek dan 19,3\% balita pendek.(Riskesdas, 2018). Sementara itu, data balita stunting di wilayah kerja Puskesmas Perawatan Jambula yaitu sebanyak 71 balita yang mengalami stunting. Dan Wilayah Kastela merupakan salah satu lokus stunting yang ada di Kota Ternate. (Data Puskesmas Perawatan Jambula, 2021)

Penyebab stunting sangat kompleks meliputi faktor sosial, lingkungan dan biologi (Unicef, 2013; WHO, 2012; World Bank, 2014). Itulah mengapa stunting memerlukan pencegahan dan penanggulangan yang serius dengan kolaborasi berbagai lembaga dan kementerian. Tujuan pengabdian ini untuk meningkatkan pengetahuan gizi masyarakat dalam rangka pencegahan stunting dengan mempersiapkan 1000 HPK.

\section{METODE PELAKSNAAN}

Kegiatan pengabdian Masyarakat ini melibatkan masyarakat secara langsung dan kerjasama antarlembaga dengan pemerintah setempat. Dilaksanakan di aula pertemuan kantor kelurahan Kastela, kecamatan Pulau Ternate, Kota Ternate. Dilaksanakan selama 1 hari yaitu pada tanggal 25 Mei 2021. Kegiatan ini merupakan kolaborasi antar Fakultas Ilmu Kesehatan Universitas Muhammadiyah Maluku Utara bekerjasama dengan organisasi profess PD IAKMI Maluku utara dan organisasi perempuan PW Nasyiatul Aisyiyah Maluku Utara. Kelompok sasaran yaitu kader dan kelompok ibu yang memiliki balita di Posyandu Kastela. Peserta yang fhadir sebanyak 25 orang. Adapun tahap kegiatan :

\subsection{Tahap Persiapan}

Pada tahapan ini,diawali dengan kegiatan perizinan untuk melaksanakan kegiatan pengabdian masyarakat di wilayah kerja Puskesmas Perawatan Jambula. Melalui survei awal lokus stunting aka ditetapkan kegiatan berpusat di Wilayah Kastela. Kemudian dilanjutkan dengan perizinan ke Keluarahan Kastela dan sosialisasi kegiatan. Adapun yang dipersiapkan selain surat perizinan, juga persiapan materi dan perlengkapan berupa masker, alat tulis, goodybag,infokus dan lainnya yang akan digunakan pada saat penyuluhan .

\subsection{Tahap Pelaksanaan}

Pada tahapan pelaksanaan, diawali dengan sambutan dari pihak kelurahan Kastela kemudian pengisian lembar pre-test, setelah itu Kegiatan inti yaitu Penyuluhan dengan tema Cegah Stunting dengan mempersiapkan 1000 HPK, diskusi tanya jawab dan diakhiri dengan pengisian lembar post test. Pada akhir penyuluhan, diadakan pembagian suvenir berupa masker dan goodybag stunting serta doorprize bagi peserta yang mampu menjawab pertanyaan yang diajukan sebagai umpan balik dari penerimaan materi yang telah disampaikan dalam kegiatan.

\subsection{Tahap Evaluasi}

Pada tahap ini, kegiatan pengabdian masyarakat dievaluasi dengan pengisian lembar post test yang pertanyaannya disamakan dengan pertanyaan pre test sebelumnya.

\section{HASIL DAN PEMBAHASAN}

Kegiatan penyuluhan berlangsung selama 1 hari dengan 2 materi inti yaitu Stunting dan 1000 HPK. Peserta yang hadir sebanyak 25 orang. Adapun hasil dari pre test dan post test menunjukkan adanya peningkatan pengetahuan masyarakat sebesar nilai rata-rata post test 6,28 lebih dari nilai ratarata pre test yaitu 4,88 . Atau terdapat 20 orang yang meningkat pengetahuannya setelah penyuluhan, 4 orang yang nilainya tetap dan hanya 1 orang yang nilai rata- rata post testnya lebih rendah dari nilai rata- rata pre test. Dapat dilihat pada tabel di bawah ini 
Tabel 1. Analisis Hasil kegiatan penyuluhan Cegah Stunting dengan Mempersiapkan 1000 HPK di Wilayah Kerja Puskesmas Perawatan Jambula

\begin{tabular}{|c|c|c|c|c|c|}
\hline & $\underline{\mathbf{N}}$ & mean & $\underline{\text { SD }}$ & Min- max & Nilai p \\
\hline Pre test & $\underline{25}$ & $\underline{4,88}$ & $\underline{1,878}$ & $\underline{1-8}$ & \\
\hline \multirow[t]{2}{*}{ Post test } & $\underline{25}$ & $\underline{6,28}$ & $\underline{1,926}$ & $\underline{2-9}$ & $\underline{0,00}$ \\
\hline & $\underline{\mathbf{N}}$ & Mean rank & & & Nilai p \\
\hline Negative rank & $\underline{1}$ & 14,0 & & & 0,00 \\
\hline Positive rank & $\underline{20}$ & $\underline{10,85}$ & & & \\
\hline$\underline{\text { ties }}$ & $\underline{4}$ & & & & \\
\hline & $\underline{25}$ & & & & \\
\hline
\end{tabular}

*Uji Wilcoxon

Tabel 1, menunjukkan adanya peningkatan nilai rata- rata pengetahuan setelah penyuluhan yaitu sebesar $1,4(\Delta \mathrm{SD} 0,11)$. Pada Akhir penyuluhan, diadakan pembagian masker dan goody bag Stunting kepada peserta.

\section{PENUTUP}

Ada peningkatan pengetahuan masyarakat mengenai penyebab stunting dan pencegahannya melalui persiapan 1000 HPK sehingga diharapkan kegiatan edukasi pada masyarakat dan kerjasama antar lembaga perlu ditingkatkan untuk menurunkan prevalensi stunting pada balita sesuai stranas 2025.

\section{DAFTAR PUSTAKA}

Cholifatun Ni'mah, Lailatul Muniroh. Hubungan tingkat Pendidikan, Yingkat pengetahuan dan Pola Asuh ibu dnegan Wasting dan Stunting Pada Balita Keluarga Miskin. Media Gizi Indonesia Vol 10 no 1 januari - Juni 2015, hal 84-90.

Dia nna, Neti Septianingsih, Jehani Fajar Pangestu. 2020. Perbedaan Pengetahuan Ibu Balita Sebelum Dan Sesudah Sesudah Diberikan Penyuluhan Tentang Stunting Melalui Media Video Dan Leaflet Di Wilayah Kerja Puskesmas Saigon Kecamatan Pontianak Timur. Jurnal Kebiadanan Khatulistiwa, Vol 6 no (1) , 2020.

Erna Kusumawati, Setiyowati Raharjo, Hesti Permatasari. 2015. Model Pengendalian Faktor Stunting Pada Usia Anak di bawah Tiga tahun. Jurnal Kesehatan Masyarakat nasional, vol 9 no 3, Februari 2015.

Farah Okky Aridiyah, Ninna Rohmawati, Mury Ririyanty. 2015. Faktor- faktor yang Mempengaruhi kejadian stunting pada Anak Balita di Wilayah Pedesaan dan Perkotaan. E-jurnal Pustaka Kesehatan, vol 3 (no 1), Januari 2015.

Fitriahadi,Enny. 2018. Hubungan Tinggi badan Ibu dengan kejadian stunting pada balita usia $24-59$ bulan. Jurnal Keperawatan dan Kebiadanan Aisyiyah, vol 14 no 1, Juni 2018. Pp15 -24

Ginna Megawati, dan Siska Wiramihardja. 2019. Peningkatan Kapasitas Kader Posyandu Dalam Mendeteksi dan mencegah stunting di Desa Cipacing Jatinangor. Dharmakarya: Jurnal Aplikasi Ipteks untuk Masyarakat, vol 8 No. 3, September 2019: 154 - 159

Kementrian Kesehatan RI, 2018. Situasi Balita Stunting di Indonesia. Buletin Jendela Data dan Informasi Kesehatan, Semester 12018.

2018. Hasil Utama Riskesdas 2018. Balai Penelitian dan Pengembangan Kesehatan, Kemenkes.

Nurul Hidayah, Marwan. 2020. Upaya Pemberdayaan Masyarakat Dalam Menciptakan Generasi Milineial Sadar Gizi Yang Bebas Stunting Melalui Kegiatan 1000 HPK. Journal Of Community engagement in Health. Vol.3 No.1. March 2020. Page.86-93 
Retty Anisa Damayanti, Lailatul Muniroh, Farapti. Perbedaan Tingkat Kecukupan Zat Gizi dan Riwayat Pemberian Asi eksklusif pada Balita Stunting dan Non Stunting. Media Gizi Indonesia, Vol 11, no 1 Januari- Juni 2016, hal 61-69.

Siswati, Tri. 2018. Stunting. Husada Mandiri: Poltekkes Kesehatan Yogyakarta. Sleman, Yogyakarta.

\section{Lampiran dokumentasi kegiatan}

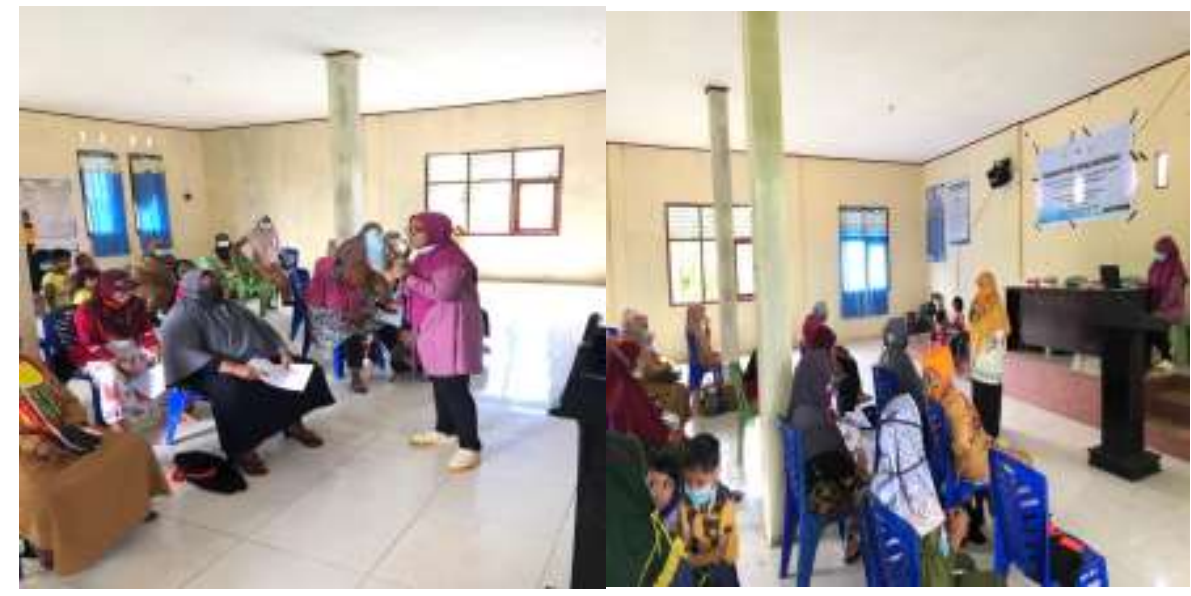

Gambar 1. Kegiatan Penyuluhan, materi 1. Stunting, Materi 2 Mengenal 1000 HPK
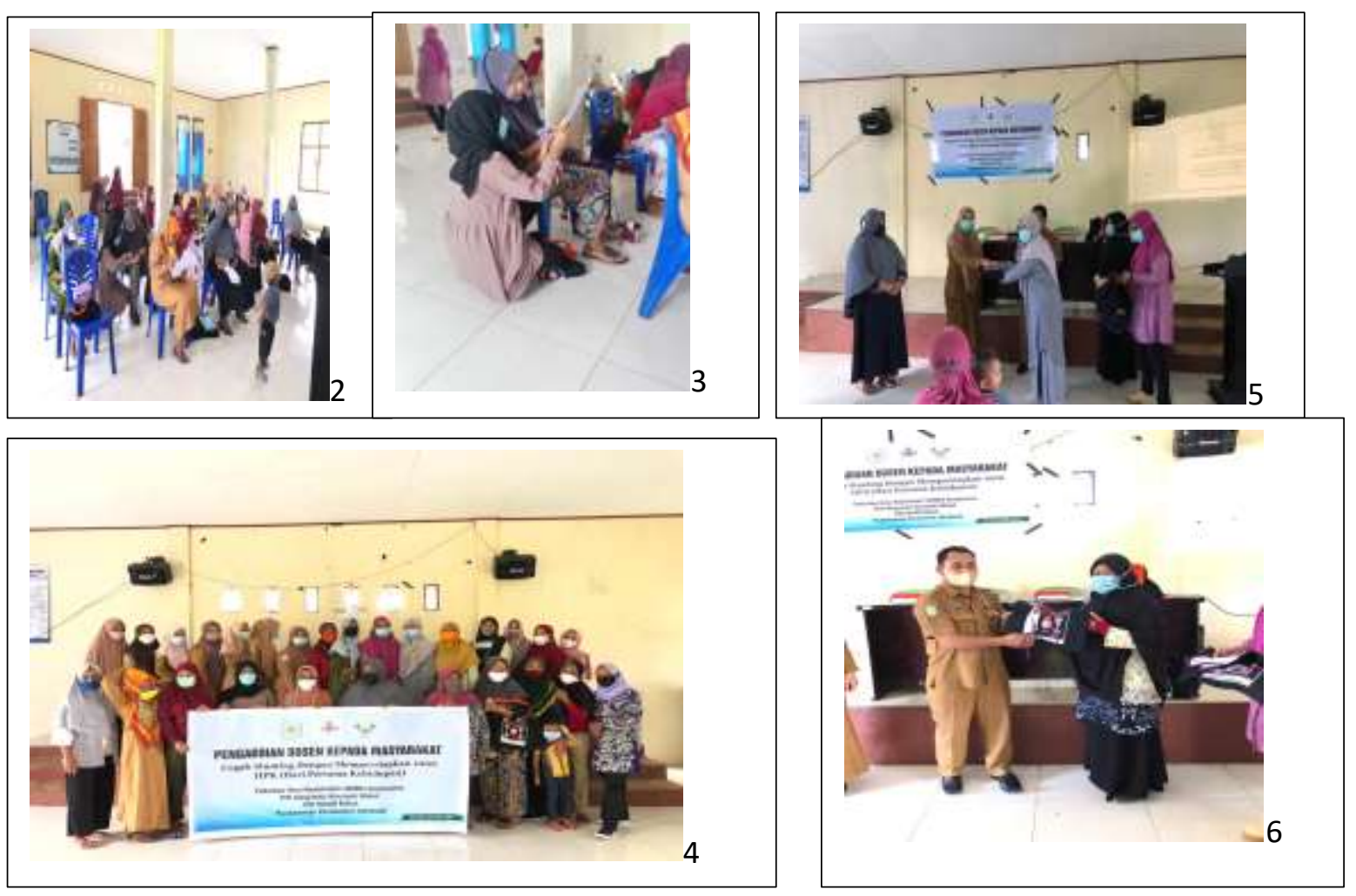

Gbr 2.pengisian lembar pre test,

gbr 3. Pengisian posttest,

gbr 4. Foto Bersama peserta dan tim Pengabdian Dosen Fikes UMMu , Pengda IAKMI Maluku Utara, dan PW Nasyiatul Aisyiyah Maluku Utara,

gbr 5 \& 6 pembagian masker dan goody bag stunting kepada perwakilan puskesmas, peserta dan kelurahan Kastela

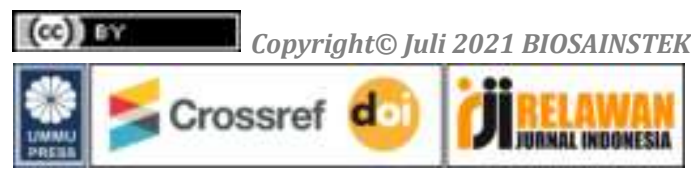

